\title{
Shelf erosion and submarine river canyons: implications for deep-sea oxygenation and ocean productivity during glaciation
}

\author{
I. Tsandev ${ }^{1}$, C. Rabouille ${ }^{2}$, C. P. Slomp ${ }^{1}$, and P. Van Cappellen ${ }^{1,3}$ \\ ${ }^{1}$ Department of Earth Sciences - Geochemistry, Faculty of Geosciences, Utrecht University, P.O. Box 80.021, \\ 3508 TA Utrecht, The Netherlands \\ ${ }^{2}$ Laboratoire des Sciences du Climat et de l'Environnement, UMR CEA-CNRS-UVSQ et IPSL, domaine du CNRS, \\ av. de la Terrasse, 91198 Gif sur Yvette, France \\ ${ }^{3}$ School of Earth and Atmospheric Sciences, Georgia Institute of Technology, Atlanta, Georgia, 30332-0340, USA
}

Received: 25 October 2009 - Published in Biogeosciences Discuss.: 2 February 2010

Revised: 31 May 2010 - Accepted: 4 June 2010 - Published: 22 June 2010

\begin{abstract}
The areal exposure of continental shelves during glacial sea level lowering enhanced the transfer of erodible reactive organic matter to the open ocean. Sea level fall also activated submarine canyons thereby allowing large rivers to deposit their particulate load, via gravity flows, directly in the deep-sea. Here, we analyze the effects of shelf erosion and particulate matter re-routing to the open ocean during interglacial to glacial transitions, using a coupled model of the marine phosphorus, organic carbon and oxygen cycles. The results indicate that shelf erosion and submarine canyon formation may significantly lower deep-sea oxygen levels, by up to $25 \%$, during sea level low stands, mainly due to the supply of new material from the shelves, and to a lesser extent due to particulate organic matter bypassing the coastal zone. Our simulations imply that deep-sea oxygen levels can drop significantly if eroded shelf material is deposited to the seafloor. Thus the glacial ocean's oxygen content could have been significantly lower than during interglacial stages. Primary production, organic carbon burial and dissolved phosphorus inventories are all affected by the erosion and rerouting mechanisms. However, re-routing of the continental and eroded shelf material to the deep-sea has the effect of decoupling deep-sea oxygen demand from primary productivity in the open ocean. $\mathrm{P}$ burial is also not affected showing a disconnection between the biogeochemical cycles in the water column and the $\mathrm{P}$ burial record.
\end{abstract}

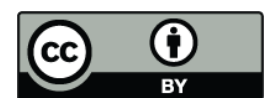

Correspondence to: I. Tsandev (tsandev@geo.uu.nl)

\section{Introduction}

The world ocean was a different environment during the glacial periods of the Pleistocene than it is today. The open oceans with colder surface water temperatures and different ocean ventilation were likely enriched in $\mathrm{CO}_{2}$. There is also evidence from sediment proxies that oxygen levels of deep-sea waters were appreciably lower than today though not anoxic. For example, trends in authigenic uranium (U) and sedimentary molybdenum (Mo) concentrations point to decreased bottom-water oxygen throughout the Atlantic and in the Pacific, coinciding with glacial periods (Francois et al., 1997; Thomson et al., 1990; Bertine and Turekian, 1973; Mangini et al., 2001; Dean et al., 1997). In the sub-arctic Pacific, authigenic $\mathrm{U}$ concentrations were higher for sediments deposited during glacial maxima, while Mo concentrations were not significantly higher, suggesting bottom waters oxygenation was lower but did not reach full anoxia (Jaccard et al., 2009). Phosphorus speciation in the North Atlantic, particularly the decrease of authigenic and iron bound phases during Heinrich events 4 and 5, points to dysaerobic conditions in the North Atlantic as well (Tamburini et al., 2002). Similarly, mass balance and modeling studies (Boyle, 1988; Broecker, 1982; Francois et al., 1997; Peacock, 2006) have concluded that deep-sea oxygen must have been lower during glacial periods.

Low glacial oxygen concentrations in the deep-sea have previously been attributed to changes in ocean circulation (Mangini et al., 2001; Schröder-Ritzrau, 2003), when the ventilation of the deep-sea is reduced, or increased primary

Published by Copernicus Publications on behalf of the European Geosciences Union. 
productivity in the surface ocean (Filippelli et al., 2007), which increases the rate at which organic matter sinks to the deep-sea, causing greater oxygen demand in deeper waters. There is, however, quite some debate about the circulation and productivity of the ocean during glacial maxima. Reconstructions of circulation for the last glacial period range from slower to faster than present day (see Table 1 in Tsandev et al., 2008). Also many reports question whether productivity was higher during glacial time (Nameroff et al., 2004; Francois et al., 1997; Dean et al., 1997). Likely, primary production was higher in some parts of the ocean, but lower in others. In a glacial-interglacial transition scenario implemented in a box model for the carbon, oxygen and phosphorus cycles in the ocean, Tsandev et al. (2008) found global ocean productivity to decrease during glacial stages compared to interglacials. In addition, reduced circulation did not lead to appreciably lower deep-sea oxygen levels.

Here, we explore two additional mechanisms that may, in combination with the climatic forcings studied in Tsandev et al. (2008), help explain the observed variations in deep-sea oxygen levels and ocean primary production during glacialinterglacial cycles. In particular we consider two processes not generally included in biogeochemical models for the glacial ocean: the transfer of suspended particulate matter via submarine canyons ("the river canyon hypothesis") and the erosion of recently deposited sediment from shelves exposed by sea level lowering ("the shelf nutrient hypothesis").

\subsection{The river canyon hypothesis}

At present, most rivers discharge on their adjacent shelves due to the high sea level stand. During glacial times, however, with sea level dropping as much as $120 \mathrm{~m}$ below present levels at the last glacial maximum (LGM) (Fairbanks, 1989; Lambeck and Chappell, 2001; Siddall, 2003) many of the world's large rivers were likely connected to submarine canyons (Fagherazzi et al., 2004; Damuth, 1977), with valley incisions extending as far as $200-760 \mathrm{~km}$ from the shelf edge (Possamentier, 2001; Rabouille et al., 2009). Under these settings, river suspended matter can be transported directly downslope via gravity driven bottom flows or turbidity currents to the abyssal plains (Khripounoff et al., 2003; Damuth, 1977; Pinet, 2006).

One notable modern day example of this type of land to ocean transport is the Congo river and its submarine canyon. It is the second largest river in the world (Milliman, 1991; Vangriesheim et al., 2009a) and it transfers particulate matter directly to the deep sea through its canyon and associated channel network (Rabouille et al., 2009; Babonneau et al., 2002). As sea level falls, as it does during glaciations, and large rivers form connections to their submarine canyons, upon shrinking of the continental shelf, an increasing fraction of the continental particulate load becomes routed directly to the deep ocean, rather than passing through the coastal shelf filter. The continental particulate material is then delivered by a mechanism similar to the Congo. If the fraction of continental material routed directly to the deep-sea is significant, this can have a potentially large effect on the biogeochemical functioning of the ocean, during periods of sea level low stand.

\subsection{The shelf nutrient hypothesis}

While organic-rich sediments are deposited on continental shelves during interglacials - with the sediments consisting of material arriving from the continents and primary production on the shelf - these same sediments are exposed as sea level recedes during glaciation. Not only does this reduce the strength of the active margin sink, but it also leads to the erosion of shelf sediments and their subsequent delivery to the open ocean (Filippelli et al., 2007). In our previous modelling work (Tsandev et al., 2008) the effect of a shrinking shelf burial sink was considered, but that of shelf erosion on carbon and nutrient transfer to the open ocean was not.

Erosion of unconsolidated shelf sediment during glacial periods has long been recognised and is based on observations of glacial sediments (Broecker, 1982; Damuth, 1977; Hay, 1994; Pollock, 1997). This material was carried to the coastal ocean by rivers or runoff and exported offshore to deep-sea fans and abyssal plains by turbidity currents via submarine canyons, where the rivers were connected to their canyons. It is not clear whether the deposition of eroded material was episodic (Hay, 1994) or continuous, spread over thousands of years (Damuth, 1977). The timing and amount of sediment delivery to the deep-sea depends on the rate of sea level change and other factors (van Heijst et al., 2001). In any case, the additional supply of large amounts of reactive marine organic-rich shelf sediments likely had an impact on the carbon and nutrient cycles of the open ocean and on deep-sea oxygen levels.

Another effect of sea level fall and shrinking of the coastal seas is that the proximal coast may disappear altogether. This allows particulate material arriving from rivers to flow directly into the open ocean, whereas this material would otherwise be trapped in proximal sediments. Hence the absence of a proximal coast has a twofold effect on the deep-sea nutrient supply: the exposed shelf becomes a source of nutrients and the continental particulate material flux can arrive to the open ocean. Thus the open ocean (and the deep-sea, where canyons transport particulate matter downslope) is fertilized with new carbon and nutrients.

Here, we use an existing biogeochemical mass balance model to assess the impact of coastal discharge through submarine canyons and shelf erosion on the biogeochemistry of the glacial ocean, by incorporating these processes in the existing glacial-interglacial climate change scenario of Tsandev et al. (2008). The results imply that shelf erosion, in combination with particulate material rerouting via submarine canyons, has the potential to significantly impact the marine 
glacial oxygen and carbon cycles and that it may help explain deep-sea oxygen depletion during glacial periods.

\section{Model description and implementation of new mechanisms}

We start from a model of the coupled marine phosphorus, organic carbon and oxygen cycles (Slomp and Van Cappellen, 2007), as adapted for a $13 \mathrm{kyr}$ residence time of phosphorus in the ocean by Tsandev et al. (2008). In the model, phosphorus is assumed to limit global ocean primary production, which is likely the case on glacial-interglacial time scales (Tyrell, 1999).

The model specifically accounts for the role of the coastal ocean as a filter for river inputs and redox dependent burial of phosphorus. It includes two coastal boxes (proximal and distal coastal zones) and a surface open ocean and deep ocean box (Fig. 1). Particulate and dissolved material enters the ocean via the proximal zone. However, particulate material is assumed to mineralize (into dissolved nutrients) or get buried as proximal sediment. In the original formulation of the model by Slomp and Van Cappellen (2007) these processes that occur in the proximal zone are not explicitly modeled and only a dissolved nutrient (P) flux - flux (1) in Fig. 1 - from the continents is implemented. Material from the proximal coastal ocean travels along the distal waters before entering the open ocean, with the exception of dust, which deposits directly to the surface of the open ocean. The effect of changing redox conditions on the burial of reactive $\mathrm{P}$ and preservation of organic carbon is implemented as well.

In this study, we use three different model settings for redox dependent burial of organic and authigenic phosphorus: (1) no redox dependent burial of organic or authigenic P; (2) Moderately redox dependent burial: $25 \%$ of the organic $P$ and $50 \%$ of the authigenic $\mathrm{P}$ fractions is redox dependent (Slomp and Van Cappellen, 2007); (3) Highly redox dependent P burial: $75 \%$ of the organic $\mathrm{P}$ and $90 \%$ of the authigenic $\mathrm{P}$ fractions is redox dependent (Tsandev and Slomp, 2009). The actual strength of redox dependence of reactive $\mathrm{P}$ burial is not well known quantitatively, thus varying this parameter is important to assess its contribution to oxygen depletion in the deep-sea. The other two reactive $\mathrm{P}$ phases (iron bound $\mathrm{P}$ and biogenic $\mathrm{P}$ ) are not varied as the complete redox dependence of iron bound $\mathrm{P}$ burial is well established, and biogenic $\mathrm{P}$ is a minor component of the reactive $\mathrm{P}$ burial in marine sediments.

The above outlined model was subjected to a spin-up procedure by applying multiple glacial-interglacial cycles to the system, as outlined in (Tsandev et al., 2008), until it equilibrates with the periodically changing climate parameters. In each cycle, we assume a $100 \mathrm{kyr}$ period of glaciation with a $30 \%$ decrease in ocean mixing, $10 \%$ decrease in river supply of $\mathrm{P}, 4^{\circ} \mathrm{C}$ lowering of sea surface temperatures and a shrinking of the continental shelves by $50 \%$. During the $10 \mathrm{kyr}$ of
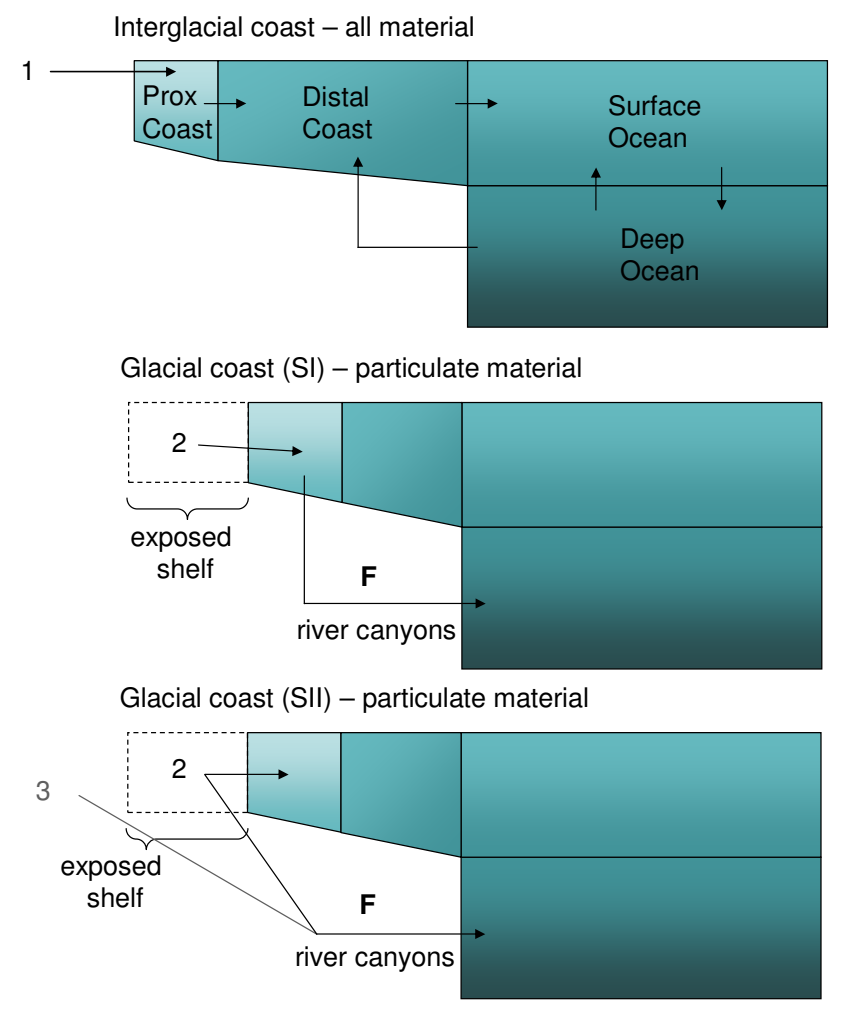

Fig. 1. Path of material in the coastal and open ocean during glaciations. Transfer of dissolved material, such as dissolved riverine P (1), always remains the same. Particulate material can become rerouted directly to the deep-sea by submarine canyons via turbidites or other gravity flows. In rerouting scenario SI a proximal zone remains to rework and trap material arriving from the continent. River canyons (fraction F) then shunt material from the proximal coast to the deep-sea, bypassing the distal coast. In rerouting scenario SII, the entire coast is bypassed and major rivers (fraction F) discharge directly to the deep-sea (3). Additionally surface sediment on exposed shelves can erode into the coastal ocean (2). This sediment represents labile marine organic matter deposited during previous interglacial stages. We assume it contains $2 \%$ organic carbon by weight and a C/P ratio of 300 . Where river canyons form, this sediment is also shunted to the deep-sea along with the continental particulate material.

deglaciation that follows, all forcings are reversed (Tsandev et al., 2008).

The shelf nutrient loading and river canyon rerouting (illustrated in Fig. 1) were then added to the other glacial forcings outlined above for a total of 6 environmental parameters perturbed during a glacial transition: ocean mixing, continental nutrient flux, surface water temperature, sea level, shelf erosion and river canyon rerouting comprise the new augmented glacial perturbation scenario. A shelf flux (2) is added to the displaced proximal zone, representing the organic material eroding from the exposed shelf. The formation of submarine canyons for major rivers is implemented by rerouting the proximal particulate organic material (POC 
and POP) to the deep-sea box for that fraction of the coast for which river canyons operate (F). This represents the transfer of the particulate load to the abyssal plains through turbidity currents in river canyons. Two different scenarios for this implementation are tested: when a proximal part of the shelf remains and separates the canyon head from the river outlet (SI) and when the river canyon intersects the entire continental shelf linking the particulate supply from exposed shelves (2) and from rivers (3) directly to the deep-sea (SII). We represent these end member situations, though in reality the global coast-line may have been comprised of a combination of such settings. The 6 environmental variables outlined are therefore the only parameters imposed on the box model. All other variables are allowed to vary dynamically and are considered as part of the system's response.

Scenario I (SI) represents a bypass of the distal coastal ocean for rivers which form submarine canyons. Therefore a small shallow proximal zone still remains between continental particulate supply and the canyon head. Thus some filtering of incoming material still occurs in the near shore zone, namely the particulate material coming from the continents is processed and largely trapped in the proximal coast. Scenario II (SII) represents a bypass of the full shelf (proximal and distal zones) as is the case for the Congo. This means that the river and canyon head are connected thus completely bypassing the continental shelf. Particulate material from the continents now travels directly to the deep-sea as does material eroded off the exposed shelves. The dissolved component (SRP), delivered by rivers to the sea, travels the same unaltered path as the water cycle and there is no difference between its behaviour under the standard glacial scenario and SI and SII. In other words, there is a decoupling between the fate of particulate and dissolved material arriving from the continents, whereby dissolved nutrients travel along the coastal zone, while particulate matter is able to avoid reworking on the coast and deposits in the deep-sea. As the coastal zone acts as a strong filter for organic material and nutrients, this re-routing of POC and POP has the effect of supplying more reactive material to the deep, where it causes additional oxygen demand.

van Heijst and Postma (2001) postulate that there is a delay between shelf emergence and connection of incisions on the shelf (canyons) to the fluvial valley. We therefore induce a rerouting mechanism for particulate organic carbon and phosphorus via submarine river canyons, 50000 years after the onset of glaciation, when sea level has receded significantly ( $25 \%$ shelf loss); we assume that at that point sea level was sufficiently low to trigger the connection of submarine canyons to their feeding rivers. Based on observations of the depositional dynamics of the Congo canyon (turbidites occurring every 2-3 years; Vangriesheim et al., 2009a), we can assume the deposition of canyon fan sediments to the deep ocean as being effectively quasi-continuous over glacialinterglacial timescales.
If bypass of the coastal zone occurred for particulate material travelling via the world's 20 major rivers (by water discharge) it would represent $45 \%$ of the riverine water flux to the coastal zone (Global NEWS database; see Beusen et al., 2005). We assess the potential effect of this rerouting mechanism by varying the extent of continental particulate matter rerouting in the context of a glacial-interglacial cycle for both scenarios.

The "shelf nutrient hypothesis" is implemented by adding a flux of particulate organic carbon to the ocean, representing new labile organic matter eroding from the aerially exposed shelves into the receded coastal ocean - flux (2) in Fig. 1.

The amount of material delivered to the sea via erosion of exposed shelves is estimated from the work of Broecker (1982) and Hay and Southam (1977). Broecker (1982) estimates that $1.2 \times 10^{5} \mathrm{Tmol}$ of carbon is transferred from aerially exposed shelves to the ocean. If we assume that this carbon is eroded over a period of $50 \mathrm{kyr}$, this is equivalent to a flux of $2.3 \mathrm{Tmol} / \mathrm{yr}$. Hay and Southam (1977) estimate an erosional flux of $150 \times 10^{14} \mathrm{~g}$ sediment/yr or $25 \mathrm{Tmol} \mathrm{C} / \mathrm{yr}$ (at $2 \% \mathrm{C}$ ). For a $50 \mathrm{kyr}$ deposition this equates to $12.5 \times 10^{5} \mathrm{Tmol} \mathrm{C}$ over a full glaciation.

Another way to estimate the erosional capacity of the shelves is to calculate their storage capacity during interglacials. The storage capacity of the shelves can be estimated from the amount of material depositing during the interglacial period both from continental supply (terrestrial org C) and in-situ production (marine org C). The estimates of the continental supply of total organic carbon (TOC) to the ocean range widely from 2.5 to $83 \mathrm{Tmol} \mathrm{TOC} / \mathrm{yr}$ (Schlünz and Schneider, 2000 - see Table 1 for list of estimate sources). Assuming 50\% is particulate (Smith and Hollibaugh, 1993; Rabouille et al., 2001) yields $1.8-41.5 \mathrm{Tmol}$ POC/yr. We take an estimate of $25 \mathrm{Tmol} / \mathrm{yr}$, which lies close to the POC load of rivers estimated by Ittekkot (1988). During sea level high stands this load is almost exclusively deposited on the continental shelves (Schlünz and Schneider, 2000; Berner, 1982, 1989; Hedges, 1992). The burial of organic C on the shelves arising from in-situ production (marine org C) is taken from the box model $(6.3 \mathrm{Tmol} \mathrm{C} / \mathrm{yr}-\mathrm{Slomp}$ and Van Cappellen, 2007) and compares to the estimate of Rabouille et al. (2001) of $8 \mathrm{Tmol} \mathrm{C} / \mathrm{yr}$. Therefore the combined terrestrial and marine carbon storage of on the shelves during sea level highstands is $31.3 \mathrm{TmolC} / \mathrm{yr}$ or a total of $3.1 \times 10^{5} \mathrm{Tmol} \mathrm{C}$ for $10 \mathrm{kyr}$ of interglacial deposition. Table 1 summarizes the above data giving the possible range of particulate material load erodable during glacial sea level low stands.

The timing and manner in which shelf erosion occurs have an important effect on material delivery to the ocean. If erosion was continuous (Damuth, 1977) then material fluxes were likely smaller and were spread over a longer period of time. If it was episodic (Hay, 1994), deposition likely occurred over a short time period with large fluxes. We assume here that shelf erosion occurred over the later stage of 
Table 1. Estimates of flux of organic matter eroded from exposed shelves and supplied to the ocean during sea level low stand of glacial periods.

\begin{tabular}{lccc}
\hline & $\begin{array}{c}\text { Low end estimate } \\
\text { (Broecker, 1982) }\end{array}$ & $\begin{array}{c}\text { Carbon storage on shelves } \\
\text { during interglacial }\end{array}$ & $\begin{array}{c}\text { High end estimate } \\
\text { (Hay and Southam, 1977) }\end{array}$ \\
\hline shelf sed. eroded (g) & $1.5 \times 10^{20}$ & $1.88 \times 10^{20}$ & $7.5 \times 10^{20}$ \\
$\operatorname{org} \mathrm{C}(\%)$ & $1 \%$ & $2 \%$ & $2 \%$ \\
$\mathrm{C} / \mathrm{P}$ & $300^{*}$ & $300^{*}$ & $300^{*}$ \\
$\operatorname{org} \mathrm{C}(\mathrm{g})$ & $1.5 \times 10^{18}$ & $3.8 \times 10^{18}$ & $15 \times 10^{18}$ \\
$\operatorname{org} \mathrm{C}(\mathrm{Tmol})$ & $1.2 \times 10^{5}$ & $3.1 \times 10^{5}$ & $12.5 \times 10^{5}$ \\
$\operatorname{org} \mathrm{C}(\mathrm{Tmol} / \mathrm{yr})^{* *}$ & 2.3 & 6.3 & 25 \\
\hline
\end{tabular}

* C/P ratio used in box model.

** Based on delivery over $50 \mathrm{kyr}$.

glaciation and the LGM, when continental shelves were most exposed. We implement continuous moderate erosion - total particulate load delivered over the last $50 \mathrm{kyr}$ of glaciation - which could represent slow uninterrupted erosion and deposition or very frequent and rapid depositional pulses such as seen in the Congo fan (Rabouille et al., 2009), on time scales much shorter than glacial transitions. We note however, there are other possible erosion scenarios, such as interspersed pulses of shelf sediment slumping to the sea at various points during glaciation. However, since we do not have good constraints to define such a scenario we test the simplified version detailed above.

\section{Results and discussion}

The connection of river canyons to their rivers upon sea level low stand, thus rerouting the particulate load directly to the deep-sea, has some effect on deep-sea oxygen levels (Fig. 2). Rerouting scenario SI, where a proximal filter still exists, has only a minor effect - rerouting particulates past the distal coastal zone lowers deep-sea oxygen levels by a few $\mu \mathrm{M}$ at most, even if all of the continental rivers were connected to submarine canyons of this form. This is likely due to the fact that in our model the proximal zone is an efficient filter of incoming continental material. Most of the continental load of POC and POP is assumed to be buried or decomposed in the proximal coast (where oxygen demand is not calculated as it is assumed shallow enough to be equilibrated with the atmosphere). Therefore, river canyons which do not bypass the proximal zone play a minor role in fertilizing the deep-sea as their input is filtered by a proximal coast which is very effective in processing and burying particulate material. Furthermore, the distal coastal zone is already significantly decreased during glacial times due to receding sea level; thus bypassing an already shrinking sink has a small effect on open ocean dynamics.
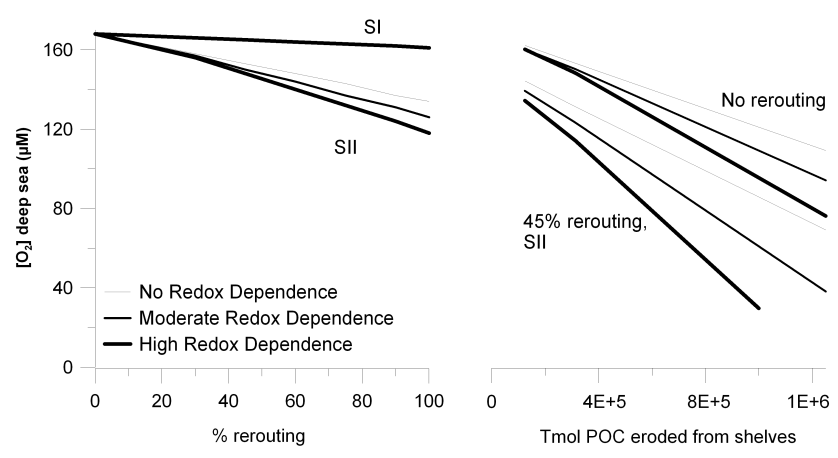

Fig. 2. Effect of submarine river canyon formation (and rerouting of particulate material) and shelf erosion on deep-sea oxygen concentrations at the last glacial maximum (LGM). Left hand side plot: rerouting of particulate material past the coast via submarine river canyons. Light gray lines represent a system where organic and authigenic $\mathrm{P}$ burial are not redox dependent. Dark grey lines represent a moderate redox dependence $(25 \%$ in organic $\mathrm{P}, 50 \%$ in authigenic P) as described in Slomp and Van Cappellen (2007). Black line represents high redox dependent burial of $\mathrm{P}(75 \%$ in organic $\mathrm{P}$, $90 \%$ in authigenic P) as implemented in Tsandev and Slomp (2009) for anoxic settings. Both rerouting scenarios detailed in Fig. 1 are plotted. Right hand side plot: a shelf erosion flux is applied as an event in the late glacial stage ( $50 \mathrm{kyr}$ ) leading to the LGM. Results are shown both for shelf erosion without river canyon rerouting and with rerouting according to scenario SII. The results for SI lie within the plotted range.

Rerouting scenario SII, on the other hand, where river canyons shunt the particulate load from rivers - flux (3) in Fig. 1 - directly to the deep-sea, is a much more efficient way to fertilize the deep ocean and increase its oxygen demand. Once the trapping ability of the proximal coast is bypassed, the particulate load of $\mathrm{C}$ and $\mathrm{P}$ arriving to the abyssal plains is significantly increased. The net effect is that, the absence of an active proximal zone filter allows the deep-sea nutrient supply to increase significantly and oxygen demand 


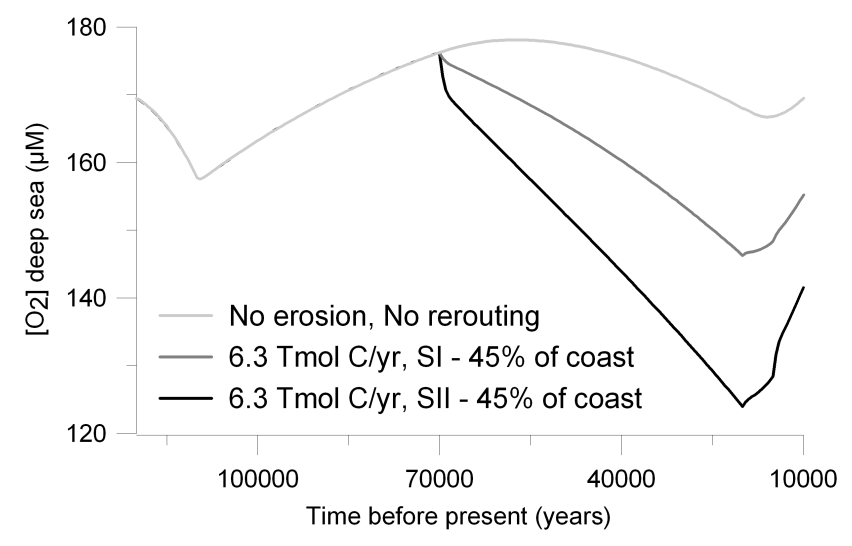

Fig. 3. The evolution of deep-sea oxygen concentrations during a glacial-interglacial cycle in the model. The light gray line represents a glacial interglacial climate change scenario as detailed in Tsandev et al. (2008) without modifications. It corresponds to the oxygen profile of Fig. 6 in (Tsandev et al., 2008). The dark gray line corresponds to the same glacial scenario with an additional flux of material eroded from exposed shelves (Table 1) and the formation of submarine canyons for major rivers (for $45 \%$ of the coast ocean) according to routing SI. The black line corresponds to the glacial scenario plus a flux of material eroded from exposed shelves and the formation of submarine canyons for major rivers ( $45 \%$ of coastal ocean) according to routing scenario SII. All runs assume a moderate redox dependence in $\mathrm{P}$ burial (Slomp and Van Cappellen, 2007).

to increase as well, causing oxygen levels to drop by up to $50 \mu \mathrm{M}$.

The erosion of shelf sediment during sea level recession - flux (2) in Fig. 1 - has a potentially significant effect on the oxygen demand in the deep-sea. The range of shelf erosion estimates, detailed in Table 1, shows that such a flux can potentially cause severe oxygen depletion in deep-sea waters (Fig. 2). Deep-sea oxygen levels can drop below $100 \mu \mathrm{M}$ during glaciations as opposed to $170 \mu \mathrm{M}$ during interglacials.

Given the relatively low oxygen concentrations attained when higher sediment loads are delivered to the ocean, we also examined the role of redox dependent burial of phosphorus. Redox dependent burial of reactive $\mathrm{P}$ can accentuate the effect of shelf erosion; when the redox sensitivity of P recycling from sediments is high, the recycled $\mathrm{P}$ fertilizes the surface ocean and creates greater respiratory demand from the settling POC. The difference between considering highly redox sensitive $\mathrm{P}$ burial and no redox sensitive $\mathrm{P}$ burial is negligible at low erosion fluxes but could result in ca. $40 \mu \mathrm{M}$ difference in deep-sea oxygen levels for high erosion fluxes. This is because in well oxygenated deep-sea environments (when carbon respiration demands are low) redox dependent $\mathrm{P}$ burial is not significant mostly because it is not observed. However, once oxygen levels drop (under higher carbon respiration demands), an accurate description of the redox dependence of reactive $\mathrm{P}$ burial becomes increasingly more important.
Combining the effects of shelf erosion and the rerouting of particulate material to the deep-sea has even stronger effects (Fig. 2). In the case of rerouting scenario SII, when the continental particulate load is augmented with material eroded from the exposed surrounding shelf, deep-sea oxygen levels can drop below $80 \mu \mathrm{M}$. Even if this synergy of shelf erosion and deep-sea deposition does not occur throughout the entire continental coastline, it could cause significantly depleted deep-sea oxygen zones in some areas where both mechanisms are at play. One example of this interplay could be the anomaly of $15-20 \mu \mathrm{M}$ of oxygen near the outlet of the Congo canyon at $4000 \mathrm{~m}$ (Vangriesheim et al., 2009b).

When we examine the temporal variation in deep-sea oxygen throughout the glacial-interglacial transition (Fig. 3) we see that the oxygen levels under a shelf erosion flux deviate from those of the glacial-interglacial scenario of Tsandev et al. (2008) (light gray line). Oxygen concentrations at the last glacial maximum (LGM) in the standard scenario are comparable to today's levels ( $167 \mu \mathrm{M}$ - from Fig. 3) while the oxygen levels when shelf erosion is present are noticeably lower (dark gray and black lines). If we use the organic matter sedimented on the shelves during an interglacial as the estimate of the amount of labile organic matter that could have eroded during glaciation $\left(3.1 \times 10^{5} \mathrm{Tmol} \mathrm{C}-\right.$ Table 1$)$ and we deliver such a load to the sea during glaciation $(6.3 \mathrm{Tmol} \mathrm{C} / \mathrm{yr}$ over $50000 \mathrm{yr}$ ), the deep ocean can reach oxygen levels near $125 \mu \mathrm{M}$. If more labile organic matter underlies the material deposited during the previous interglacial still further oxygen depletion is possible.

Given the impact of shelf erosion and submarine river canyons on deep-sea oxygen levels, we look at the corresponding effect on the other associated biogeochemical cycles in the context of glacial-interglacial climate change (Fig. 4). We examine the effect of augmenting the glacialinterglacial changes implemented in Tsandev et al. (2008) with both rerouting mechanisms by river canyons, shelf erosion, and their combined effects. Reservoir and flux values for the biogeochemical cycles of $\mathrm{P}$ and $\mathrm{C}$ at the last glacial maximum (LGM) are compared to the standard glacialinterglacial scenario implemented in Tsandev et al. (2008) (light gray bars). The net effect of all the mechanisms is some ocean fertilization. Dissolved reactive P (SRP) increases in the deep-sea and correspondingly so does primary production. Rerouting scenario SI has a negligible effect while shelf erosion and rerouting scenario SII have a more pronounced effect. The combination of shelf erosion and river canyon rerouting has the greatest impact on the fertility of the open sea. However, as primary production is $11 \%$ lower during the LGM than during the interglacial period (result of Tsandev et al., 2008 - Fig. 6), this fertilisation only brings the production in the ocean at the LGM close to interglacial levels but not much above them. Thus the net trend of a low production ocean during glacial times still remains despite greatly increased oxygen demand in the deep-sea. 


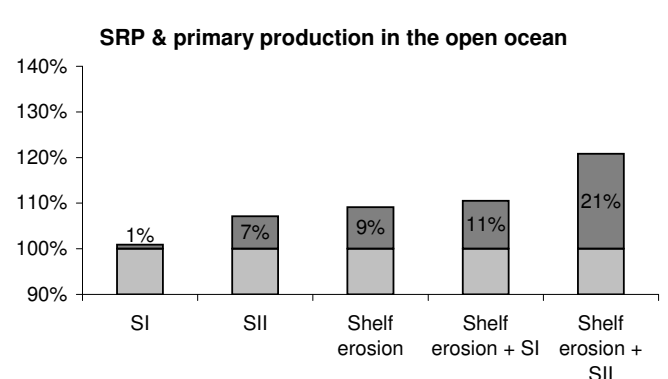

SII

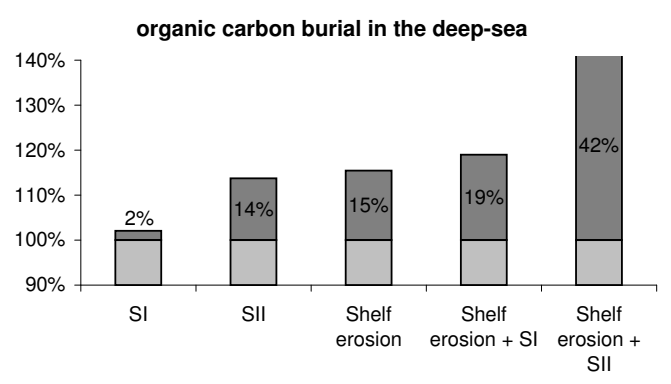

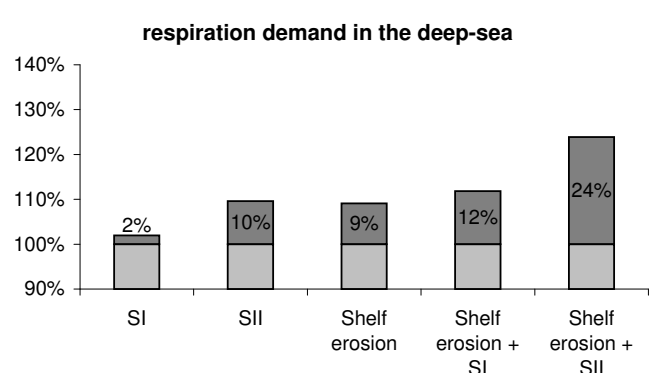

reactive $P$ burial in the deep-sea

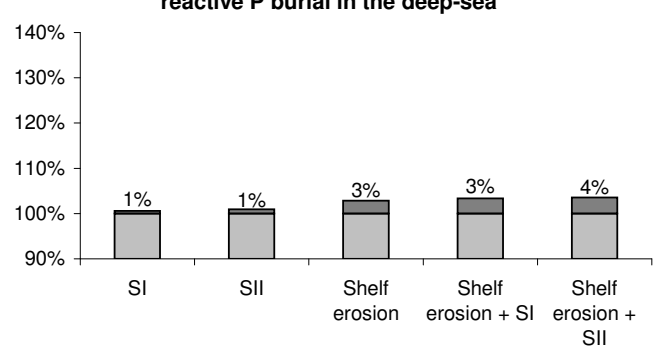

Fig. 4. Effect of shelf erosion and rerouting of particulate material during glaciations on the biogeochemical cycling of the open ocean at the last glacial maximum (LGM). Light gray bars represent the values of biogeochemical variables (dissolved P reservoir (SRP), primary production, respiration demand, organic $\mathrm{C}$ and reactive $\mathrm{P}$ burial) at the LGM for the standard glacial-interglacial scenario used in Tsandev et al. (2008). Dark gray bars illustrate the change of value in these variables under different scenarios implemented in this paper. The 5 scenarios include the standard glacial scenario of Tsandev et al. (2008) plus formation of submarine canyons according to scenario SI and formation of submarine canyons according to SII, the erosion of $6.3 \mathrm{Tmol} \mathrm{C} / \mathrm{yr}$ over $50 \mathrm{kyr}$ (shelf erosion), and a combination of the above. In all cases, moderate redox dependent burial of organic and authigenic P is assumed as per Slomp and Van Cappellen (2007).

An interesting result is the respiration demand created in the open ocean. While the oxygen demand roughly follows the primary production trend it is actually higher for rerouting scenario SII than for shelf erosion. Also, while primary production remains relatively low (only $7 \%$ higher) under SII, oxygen demand increases (10\% higher) and similarly when erosion and SII are combined. This implies that, in the case of routing scenario SII, the rerouting of material to the deep-sea has the effect of decoupling deep-sea oxygen levels from the biogeochemical activity of the ocean, making low oxygen levels possible even for an ocean which is not fertilized enough to create a high oxygen demand from in-situ primary production.

The variable most affected by river canyons and the particulate load from the continents and shelves is organic carbon burial in the deep-sea which increases twice as much as the dissolved phosphate reservoir. Therefore, most of the carbon arriving from the continent is buried in ocean sediments, which helps explain why ocean productivity can remain relatively low despite high loads of labile organic material. These model results are supported by observations of elevated organic matter burial in glacial sediments for various locations, including the Amazon fan (Goñi , 1997), the Gulf of Mexico (Newmann et al., 1973) and the continental margins of Africa and South America (Mollenhauer et al., 2004). Phosphorus burial on the other hand is nearly unaffected by the resulting ocean fertilization; even with large amounts of labile material supplied from the shelves, deep-sea $\mathrm{P}$ burial increases by no more than $4 \%$. This is because, as oxygen levels fall, $\mathrm{P}$ is actively recycled to the water column. Therefore the fertilization of the ocean by labile organic material from land and coast goes unrecorded in the buried P record. Our finding that $\mathrm{P}$ burial records do not change significantly over glacial time scales is in accordance with observations for sediments from various ocean regions published by Tamburini and Föllmi (2009). In contrast, Filippelli et al. (2007) finds increased $\mathrm{P}$ burial at several high production sites in the Southern Ocean. Note, however, that our box model results refer to a total ocean average where productivity was not greater during glaciation and direct comparison to specific sites is difficult as local parameters often influence behaviour. Our finding that phosphorus burial cannot be readily used as a proxy for ocean productivity or organic matter flux to the seafloor is an important one; $\mathrm{P}$ burial is dependent on redox conditions in the sediment which can change the trend in burial irrespective of the activity of the overlying water column and decouple the $\mathrm{P}$ record from the productivity of the ocean. 


\section{Conclusion and implications}

The effect of rerouting particulate material to the deep ocean via submarine river canyons promotes lower oxygen levels during sea level low stands. More importantly, it also decouples deep-sea oxygen content from the productivity of the surface ocean. That is, the open ocean does not need to be very active in terms of primary production to cause oxygen demand in the deep-sea during glaciations. However, this effect is only felt strongly when the coast is completely bypassed by canyon incisions all the way into the river mouth and much less so if a proximal coastal filter remains between the rivers and their submarine canyons. Though this result may be surprising, giving the amount of reactive material that is being shunted to the open ocean, it is not as surprising in the context of a glacial scenario. Rerouting of the particulate matter delivered by major rivers, occurs in the late stage of glaciation when sea level is already low. Continental shelves (the distal zone) are already shrunk by $25 \%$ and another $25 \%$ is lost as the major rivers begin to form canyons and discharge particulate material to the deep. Thus, removing the distal zone for half of the continental supply has a reduced effect, as the already shrinking continental shelves play an increasingly smaller role towards the end of the glacial period. In the presence of a proximal shelf, there will always be significant trapping of material in the coastal ocean thus dampening the effect of submarine canyons.

If large amounts of organic matter were available on continental shelves and became eroded during sea level low stands, the glacial ocean's oxygen would be markedly different at the LGM. We do not know exactly what amounts of erodible labile shelf sediment are most likely, but within the range of values suggested in the literature we already see an impact on the ocean's oxygen levels during sea level low stands. The arrival of extra particulate organic matter from the erosion of exposed shelves, constitutes a supply of new labile material to the ocean. As sea level continuously recedes during glaciation, more and more shelves become exposed to erosion and, through that erosion, the coast becomes a source of carbon and nutrients to the ocean, rather than a filter (which is its role during interglacial stages). Depending on the amount of material being supplied and the manner in which it is delivered, this mechanism can have a potentially great impact on open ocean processes. If, late in the glacial period, the sediment deposited on shelves during interglacial sea level high-stands $\left(3.1 \times 10^{5} \mathrm{Tmol} \mathrm{C}\right)$ becomes eroded and delivered to the ocean, the oxygen demand in the deep-sea increases enough to draw deep-sea oxygen levels down to values near $125 \mu \mathrm{M}$.

Therefore, although we cannot say that there was enough shelf organic matter to drive complete oxygen depletion in the deep-sea during glaciations, we can say that there was at least enough organic matter on the shelves to cause significant oxygen demand and do so without affecting the fertility of the open ocean to the same extent during glacial times.
A boost of organic matter to the ocean invariably creates a higher nutrient load in the open ocean and increases primary production and burial of carbon. Thus the ocean can become somewhat fertilized without invoking fertilization by micronutrients such as iron. And deep-sea oxygen levels can be lowered without invoking any further slowdown in circulation or drastic increases in primary production. Therefore, erosion processes on the continent and shelves can help explain low oxygen levels in the deep-sea at the LGM in addition to previous proposals that circulation slowdown or iron fertilization caused the oxygen demand in the deep-sea at glacial times.

For an ocean already depleted in oxygen, the redox dependent burial of calcium associated phases and organic phases of phosphorus becomes increasingly important as it is a positive feedback, fueling further oxygen depletion by recycling $\mathrm{P}$ from sea sediments. For moderately oxygenated deep-sea waters $\left(>100 \mu \mathrm{M}\left[\mathrm{O}_{2}\right]\right)$, the role of redox dependent $\mathrm{P}$ burial on oxygen depletion is small (Fig. 2). As Fig. 4 shows, the redox dependent nature of $P$ burial can leave the reactive $P$ reservoir in sediments quite insensitive to even major alterations of the marine biogeochemical cycles. It is therefore paramount that more investigations are done on the mechanisms by which $P$ is recycled from sediments under changing redox conditions and a better quantitative relationship be established between oxygen in overlying waters and reactive $\mathrm{P}$ burial.

In summary, we show that the erosion of shelf sediments and formation of submarine canyons by large rivers have a potentially significant impact on ocean oxygen levels during glacial transitions. The continental shelves, which during interglacial stages act as sinks of carbon and phosphorus coming from land, can turn into sources of those elements and the shunting of labile material to the deep-sea can decouple the deep-ocean's oxygen demand from the primary production of the overlying surface ocean. We also show that under declining redox conditions the $\mathrm{P}$ burial record is completely decoupled from the other biogechemical cycles as the redox dependent nature of $\mathrm{P}$ burial becomes increasingly important when bottom water oxygen levels drop near and below $100 \mu \mathrm{M}$.

Acknowledgements. This research was made possible by financial support from the Netherlands Organisation for Scientific Research (VIDI and van Gogh grants to C. P. Slomp) and Utrecht University (HiPo grant to C. P. Slomp). C. Rabouille thanks the Biozaire programme and the CHACCRA-RiOMAr project, who provided funding. This is LSCE contribution 4212.

Edited by: K. Küsel 


\section{References}

Babonneau, N., Savoye, B., Cremer, M. and Klein, B.: Morphology and architecture of the present canyon and channel system of the Zaire deep-sea fan, Mar. Petrol. Geol., 19(4), 445-467, 2002.

Berner, R. A.: Burial of organic carbon and pyrite sulfur in the modern ocean: its geochemical and environmental significance, Am. J. Sci., 282, 451-473, 1982.

Berner, R. A.: Biogeochemical cycles of carbon and sulfur and their effect on atmospheric oxygen over phanerozoic time, Paleogeogr. Paleoclimatol. Paleoecol., 75, 97-122, 1989.

Bertine, K. and Turekian, K. K.: Molybdenum in marine deposits, Geochim. Cosmochim. Ac., 37, 1415-1434, 1973.

Beusen, A. H. W., Dekker, A. L. M., Bowmann, A. F., Lunwig, W., and Harrison, J.: Estimation of global river transport of sediments and associated particulater $\mathrm{C}, \mathrm{N}$, and $\mathrm{P}$, Global Biogeochem. Cy., 19(4), GB4S05, doi:10.1029/2005GB002453, 2005.

Boyle, E. A.: Vertical oceanic nutrient fractionation and glacial interglacial $\mathrm{CO}_{2}$ cycles, Nature, 331(6151), 55-56, 1988.

Boyle, E. A.: Quaternary deep-water paleoceanography, Science, 249(4971), 863-870, 1990.

Broecker, W. S.: Glacial to interglacial changes in ocean chemistry, Prog. Oceanogr., 11, 151-197, 1982.

Damuth, J. E.: LAte Quaternary sedimentation in the western equatorial Atlantic, Geol. Soc. Am. Bull., 88, 695-710, 1977.

Dean, W. E., Gardner, J. V., and Piper, D. Z.: Inorganic geochemical indicators of glacial-interglacial changes in productivity and anoxia on the California continental margin, Geochim. Cosmochim. Ac., 61(21), 4507-4518, 1997.

Fagherazzi, S., Howard, A. D., and Wiberg, P. L.: Modeling fluvial erosion and deposition on continental shelves during sea level cycles, J. Geophys. Res., 109(F3), F03010, doi:10.1029/2003JF000091, 2004.

Fairbanks, R. G.: A 17000 glacio-eustatic sea level record - influence of glacial melting rates on the Younger Dryas event and deep-ocean circulation, Nature, 342(6250), 637-642, 1989.

Filippelli, G. M., Latimer, J. C., Murray, R. W., and Flores, J. A.: Productivity records from the Southern Ocean and the equatorial Pacific Ocean: Testing the glacial ShelfNutrient Hypothesis, Deep-Sea Res., 54(21-22), 2443-2452, doi:10.1016/j.dsr2.2007.07.021, 2007.

Francois, R. Altabet, M. A., Yu, E. F., Sigman, D. M., Bacon, M. P., Bohrmann, G., Bareille, G., and Labeyrie, L. D.: Contribution od Southern Ocean surface-water stratification to low atmospheric $\mathrm{CO}_{2}$ concentrations during the last glacial period, Nature, 389(6654), 929-935, 1997.

Goñi, M. A.: Records of terrestrial organic matter composition in Amazon Fan sediments, in Proceedings of the Ocean Drilling Program, Scientific Results, vol. 155, edited by: Flood, R. W., Piper, D. J. W., and Peterson, L. C., Ocean Drill. Program, College Station, Texas, 519-530, 1997.

Hay, W.: Pleistocene-Holocene fluxes are not the Earth's norm, in: Material fluxes on the surface of the Earth, National Academy Press, Washington, DC, 15-27, 1994.

Hay, W. and Southam, J. R.: Modulation of Marine sedimentation by the continental shelves, in: Marine Science 6: The fate of fossil fuel $\mathrm{CO}_{2}$ in the oceans, Plenum Press, New York, 596604, 1977.
Hedges, J. I.: Global biogeochemical cycles: progress and problems, Mar. Chem., 39, 67-93, 1992.

Ittekkot, V.: Global trends in the nature of organic matter in river suspensions, Nature, 332, 436-438, 1988.

Jaccard, S. L., Galbraith, E. D., Sigman, D. M., Haug, G. H., Francois, R., and Pedersen, T. F.: Subarctic Pacific evidence for glacial deepening of the oceanic respired carbon pool, Earth Planet. Sc. Lett., 277(1-2), 156-165, doi:10.1016/j.eps1.2008.10.017, 2009.

Khripounoff, A., Vangriesheim, A., Babonneau, N., Crassous, P., Dennielou, B., and Savoye, B.: Direct observation of intense turbidity current activity in the Zaire submarine valley at $4000 \mathrm{~m}$ water depth, Mar. Geol., 194(3-4), 151-158, doi:10.1016/S0025-3227(02)00677-1, 2003.

Lambeck, K. and Chappell, J.: Sea level change through the last glacial cycle, Science, 292(5517), 679-685, 2001.

Mangini, A., Jung, M., and Laukenmann, S.: What do we learn from peaks of uranium and of manganese in deep-sea sediments?, Mar. Geol., 177, 63-78, 2001.

Milliman, J. D.: Flux and fate of fluvial sediment and water in costal seas, in: Ocean Margin processes in global change, edited by: Mantoura, R. F. C., Martin, J.-M., and Wollast, R., Wiley and Sons, New York, 69-91, 1991.

Mollenhauer, G., Schneider, R. R., Jennerjahn, T., Muller, P. J., Wefer, G.: Organic carbon accumulation in the South Atlantic Ocean: its modem, mid-Holocene and last glacial distribution, Global Planet. Change, 40(3-4), 249-266, 2004.

Müller, P. J. and Suess, E.: Productivity, sedimentation rate and sedimentary organic matter in the oceans: I. Organic carbon preservation, Deep-Sea Res., 26, 1347-1362, 1979.

Nameroff, T. J., Calvert, S. E., and Murray, J. W.: Glacialinterglacial variability in the eastern tropical North Pacific oxygen minimum zone recorded by redox-sensitive trace metals, Paleoceanography, 19(1), PA1010, doi:10.1029/2003PA000912, 2004.

Newman, J. W., Parker, P. L., and Behrens, E. W.: Organic carbon ratios in Quaternary cores from the Gulf of Mexico, Geochim. Cosmochim. Ac., 37, 225-238, 1973.

Peacock, S., Lane, E., and Respero, J. M.: A possible sequence of events for the generalized glacial-interglacial cycle, Global Biogeochem. Cy., 20(2), GB2010, doi:10.1029/2005GB002448, 2006.

Pinet, P. R.: Marine sedimentation, in: Innovation to Oceanography, 4 edition, Jone and Bartlett Publishers, London, 95-135, 2006.

Pollock, D. E.: The role of diatoms, dissolved silicate and Antarctic glacial/interglacial climatic change: A hypothesis, Global Planet. Change, 14(3-4), 113-125, 1997.

Possamentier, H. W.: Lowstand alluvial bypass systems: Incised vs. unincised, Am. Assoc. Petr. Geol. B., 85(10), 1771-1793, 2001.

Rabouille, C., Mackenzie, F. T., and Ver, L. M.: Influence of the human perturbation on the carbon, nitrogen and oxygen biogeochemical cycles in the global coastal ocean, Geochim. Cosmochim. Ac., 65(21), 3615-3641, 2001.

Rabouille, C., Caprais, J.-C., Lansard, B., Crassous, P., Dedieu, K., Reyss, J. L., and Khripounoff, A.: Organic matter budget in the Southern Atlantic continental margin close to the Congo canyon: In situ measurements of sediment oxygen consumption, Deep-Sea Res. Pt. II, 56(23), 2223-2238, 
doi:10.1016/j.dsr2.2009.04.005, 2009.

Smith, S. V. and Hollibaugh, J. T.: Coastal metabolism and the oceanic organic carbon balance, Rev. Geophys., 31, 75-89, 1993.

Schröder-Ritzrau, A., Mangini, A., and Lomitschka, M.: Deep-sea corals evidence periodic reduced ventilation in the North Atlantic during the LGM/Holocene transition, Earth Planet. Sc. Lett., 216(3), 399-410, doi:10.1016/S0012-821X(03)00511-9, 2003.

Schlünz, B. and Schneider, R. R.: Transport of terrestrial organic carbon to the oceans by rivers: re-estimating flux- and burial rates, Int. J. Earth Sci., 88, 599-606, 2000.

Siddall, M., Rohling, E. J., Almogi-Labin, A., Hemleben, C., Meischner, D., Schmelzer, I., and Smeed, D. A.: Sea level fluctuations during the last glacial cycle, Nature, 423(6942), 853-858, doi:10.1038/nature01690, 2003.

Slomp, C. P. and Van Cappellen, P.: The global marine phosphorus cycle: sensitivity to oceanic circulation, Biogeosciences, 4, 155171, doi:10.5194/bg-4-155-2007, 2007.

Tamburini, F., Huon, S., Steinmann, P., Grousset, F. E., Adatte, T., and Föllmi, K. B.: Dysaerobic conditions during Heinrich events 4 and 5: Evidence from phosphorus distribution in a North Atlantic deep-sea core, Geochim. Cosmochim. Ac., 66(23), 4069-4083, 2002.

Tamburini, F. and Föllmi, K. B.: Phosphorus burial in the ocean over glacial-interglacial time scales, Biogeosciences, 6, 501513, doi:10.5194/bg-6-501-2009, 2009.

Thomson, J., Wallace, H. E., Colley, S., and Toole, J.: Authigenic Uranium in Atlantic sediments of the last glacial stage - a diagenetic phenomenon, Earth Planet. Sc. Lett., 98(2), 222-232, 1990.
Tsandev, I., Slomp, C. P., and Van Cappellen, P.: Glacialinterglacial variations in marine phosphorus cycling: Implications for ocean productivity, Global Biogeochem. Cy., 22(4), GB4004, doi:10.1029/2007GB003054, 2008.

Tsandev, I. and Slomp, C. P.: Modeling phosphorus cycling and carbon burial during Cretaceous Oceanic Anoxic Events, Earth Planet. Sc. Lett., 286, 71-79, doi:10.1016/j.eps1.2009.06.016, 2009.

Tyrell, T.: The relative influences of nitrogen and phosphorus on oceanic primary production, Nature, 400, 525-531, 1999.

Vangriesheim, A., Khripounoff, A., and Crassous, P.: Turbidity events observed in-situ along the Congo submarine channel, Deep-Sea Res. Pt. II, 56(23), 2208-2222, doi:10.1016/j.dsr2.2009.04.004, 2009.

Vangriesheim, A., Pierre, C., Aminot, A., Metzl, N., Baurand, F., and Caprais, J.-C.: The influence of Congo River discharges in the surface and deep layers of the Gulf of Guinea, Deep-Sea Res. Pt. II, 56(23), 2183-2196, doi:10.1016/j.dsr1012.2009.1004.1002, 2009.

van Heijst, M. W. I. M. and Postma, G.: Fluvial response to sea level changes: a quantitative analogue, experimental approach, Basin Res., 13(3), 269-292, 2001.

van Heijst, M. W. I. M., Postma, G., Meijer, X. D., Snow, J. N., and Anderson, J. B.: Quantitative analogue flume-model study of river-shelf systems: principles and verification exemplified by the Late Quaternary Colorado river-delta evolution, Basin Res., 13(3), 243-268, 2001. 